\title{
THE COMPETITIVENESS OF SMALL AND MEDIUM SIZED ENTERPRISES OF STONE INDUSTRY
}

UDC: 658.115:622.323(497.11)

Original Scientific Paper

\section{Tayebeh NIKRAFTAR}

University of Tehran, Faculty of Entrepreneurship, Tehran Province, Tehran, Khazaneh Bokharaee, N St No. 18, Kargar, Iran

E-mail: nikraftar@ut.ac.ir

Paper received: 27.08.2016.; Paper accepted: 10.11.2016.

\begin{abstract}
This study aims to examine the antecedents of stone firms competitiveness based on Porter's model. Questionnaire data collected from 200 senior stone firms' members in Iran. The results show that all aspects of porter model have positive effects on competitiveness. Also, factor conditions contributed significantly to enterprises competitiveness and are the most important predictor among all other of the antecedents of competitiveness. Because the data is limited to stone industry, future studies need to validate these results in other industries. The findings of this study suggest that, to increase competitiveness ability, the stone firms should invest in developing and enhancing factor conditions. The value of this paper lies in its contribution to understanding better the predictors of competitiveness. Particularly, the paper adds to the existing literature by showing that the key success factors for competitiveness are factor and demand conditions. People who want to work for the industry should promote the factor and demand conditions. It is better that they work in the areas which have enough demand and factor conditions.
\end{abstract}

Keywords: Competitiveness, Porter's Model, Stone industry, Iran.

\section{INTRODUCTION}

Firms' cooperation with other companies becomes a strategic alternative and allows them to gain competitive advantages. If a large number of firms are involved, relationships can be created among them so as to form a compact network. These interorganizational networks normally develop in a specific geographical location in the form of clusters (Capó-Vicedo et al., 2008).

Small and medium enterprises in clusters are considered the backbone of economic growth in all countries. They contribute in providing job opportunities, act as a supplier of goods and services to large organizations (Singh et al., 2008).

Why do some SMEs grow so much faster and have much better trade performance than others? What are the crucial factors behind such divergences? Questions such as these motivate a concern for competitiveness of SMEs. Although the concept of competitiveness has proven to be controversial, the importance of the underlying challenges makes unlikely that this issue will lose the attention of policy makers soon. Competitiveness of a company is mostly dependent on its ability to perform well in dimensions such as cost, quality, delivery, dependability and speed, innovation and flexibility to adapt itself to variations in demand (Carpinetti et al., 2000). This paper focuses on the development of competitive advantage at the firm level, particularly in competitive advantage in small- and medium-sized enterprises (SMEs). The development of a competitive advantage is often seen as a process through which entrepreneur aims to improve an SME's performance and sustain a market position whether domestically or internationally.

Iran has many stone clusters including different SMEs. Therefore, the aim of this study was to evaluate effective factors on competitiveness of the existing SME enterprises in the stone cluster based on Porter's Model (1990). 


\section{THEORY}

\section{Porter's Diamond Model Theory}

"Competitive advantage" is a popular term in many fields, and broader definitions include national, industrial, and firm levels. The advantage is termed "competitive" when what the firm does is unique and difficult to replicate (Zhao, Watanabe and Griffy-Brown, 2009).

Porter developed the "diamond model"". This model was first comprehensively proposed and elaborated in Porter's book The Competitive Advantage of Nations (Porter, 1990). The model was raised to form a diamond frame which determines industrial competitiveness and explains why some nations gain the competitive advantage in international markets. There are four determinants that allow industries to build competitive advantage: (1) factor conditions; (2) demand conditions; (3) firm strategy structure and rivalry; and (4) related and supporting industries (Sun et. al, 2010).

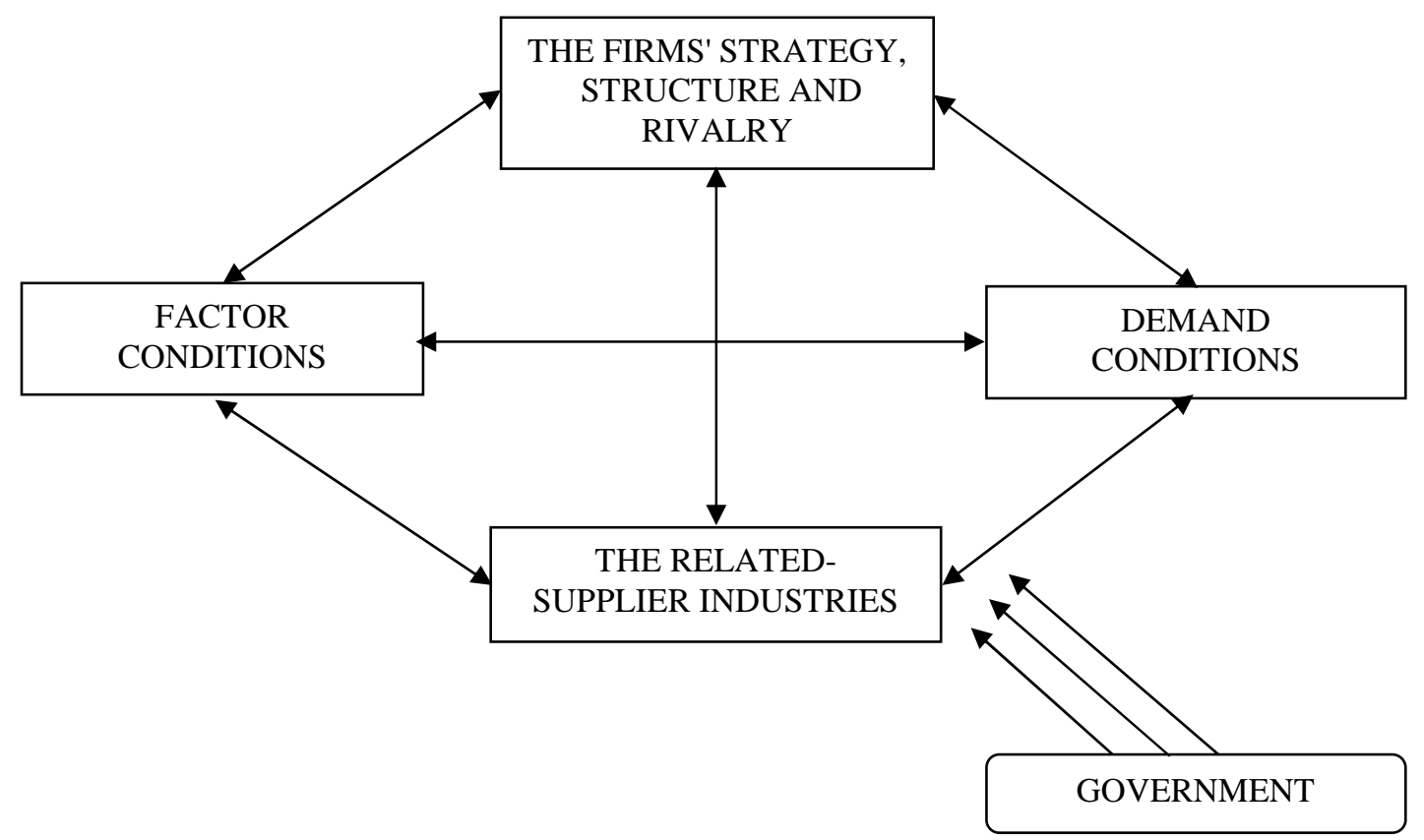

Figure 1: The determining factors of diamond model (Porter, 1990)

\section{Demand Conditions as an antecedent of Competitiveness}

Porter (1990) suggests that the demand conditions which indicate the nature of home demand formed the second broad determinant of national competitive advantage (Sun et. al, 2010). A competitive advantage is meaningful if it is related to an attribute valued by the market. Customers need to perceive a consistent difference in important attributes between the producer's products or services and those of its competitors. These differences must relate to some product/delivery attributes which are among the key buying criteria for the market' Product/delivery attributes are those variables that impact the customers' perceptions of the product or service, its usefulness, and its availability. Some examples of such attributes are product quality, price and after-sale service (Agha, Alrubaiee and Jamhour, 2012).

\section{Factor Conditions as an antecedent of Opportunity Recognition}

In Porter's model, all human resource, raw material, knowledge, capital and even infrastructures are assumed as factors. The "condition" of these factors (the quality, importance and even scarcity) is more important than the endowment and cost of them because it is possible that easy access to large amount of factors results in a kind of "inefficiency" of their utilization. Moreover, if other three dimensions are in a favorable situation for an industry, the pressure of competition would be high but for the firms which are committed to work in the sector this scarcity of factors could be constructive only if 
firms get the signal of this shortage well (Mehrizi and Pakneiat, 2008).

The resource-based view (RBV) emphasizes the firm's resources as the fundamental determinants of competitive advantage and performance. It adopts two assumptions in analyzing sources of competitive advantage, see for instance (Barney, 1991; Peteraf and Barney, 2003).

\section{Related and Supporting Industries as an antecedent of Opportunity Recognition}

The introduction of related and support industry clusters as a separate determinant of national competitive advantage has been viewed as one of the most important contributions of Porter's Diamond Theory. According to Porter (Porter, 1998), it is the external economies of related and support industry clusters, such as networks of specialized input providers, institutions and the spill-over effects of local rivalry, that become the true source of competitive advantage. The cluster represents an environment in which learning, innovation, and operating productivity can flourish. He believes that these kinds of localized clusters are prominent features of virtually any advanced economy but they lack in developing countries, which limits productivity growth in those economies (Smith, 2010).

\section{Firm Strategy, Structure and Rivalry as an antecedent of Opportunity Recognition}

Firms' strategy, structure and rivalry are measures of situations that explain how a sector is originated, systemized and managed and the nature of domestic competition that could support a nation's achievement and sustained competitive advantage (Tuna, 2006).

According to Porter (Porter, 1990), to be competitive, firms must continually improve operational effectiveness in their activities while simultaneously pursuing distinctive rather than imitative strategic positions. His argument is that the existence of geographical clusters encourages both of these requirements for firm competitiveness, by initiating the formation of regionally-based relational assets external to individual firms but of major benefit to their competitive performance.

Schumpeter picked up the role of the entrepreneur in improving growth. In his theory of entrepreneurship, Joseph Schumpeter (Schumpeter ,1911) argued that, in the face of competition and declining profits, entrepreneurs are driven to make technical and financial innovations and that the spurts of activity resulting from these innovations generate (irregular) economic growth. Through a process of 'creative destruction' waves of innovation hit different industries at different points in time - providing widely different entrepreneurial profit across industries.

\section{Assumptions: (Figure2)}

H1: Demand Conditions will be positively associated with SMEs Competitiveness

H2: Factor Conditions will be positively associated with SMEs Competitiveness

H3: Related and Supporting Industries will be positively associated with SMEs Competitiveness

H4: Firm Strategy, Structure and Rivalry will be positively associated with SMEs Competitiveness

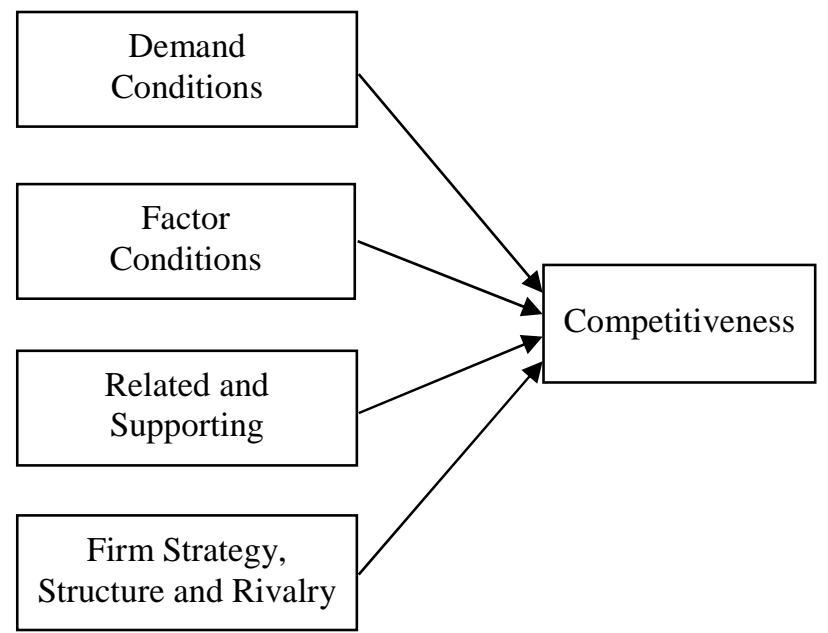

Figure 2: Conceptual Framework of Research

\section{METHODOLOGY}

This research is quantitative research. Data was gathered through a questionnaire.

- Research design and data collection: Data were collected from SME enterprises of stone industry in Iran. 250 senior managers participated in this research. 200 valid returned questionnaires were received from senior managers.

- Instrumentation: The instrument for the senior manager members included two sections: section 1 contained questions based on Porter's 
Model (Porter, 1990). The questions are designed based on literature review and interview by 20 experts. Responses were fivepoint Likert-type scales. Section 2 contained demographic items

- Data Analysis: First, an exploratory factor analysis with varimax rotation was conducted on all survey items. The results of the factor analysis indicated that the groupings of factors were exactly the same as the instrument factor analyses reported in the past research, and no items were deleted in this stage (Table 1). Next, the researchers conducted a confirmatory factor analysis to evaluate the factor structure, and Cronbach's alpha values were used to rate the reliability of the instrument. Standard of being converged validity is based on the average variance of exit (AVE) more than 0.5. Diverged validity was measured by comparing AVE square root to correlations among latent variables (Table 2). The present research used 2 measures of Cronbach's alpha and combined reliability factor in order to identify questionnaire reliability. In all variables, Cronbach's alpha coefficients are more than a minimum value (0.7). Unlike Cronbach's alpha assuming implicitly whose indexes have the same weights, the combined reliability relies on real factorial loads of each factor, and therefore, it gives a better measure for reliability. Combined reliability must obtain a value more than 0.7 to reflect the inner consistency of factors. Tables 1 and 2 represent results of reliability and validity of measuring instrument completely. Measuring tools have good validity (content, convergent, divergent) and good reliability (factor loading, composite reliability coefficient, Cronbach's alpha coefficient). (Table 3) Summarizes the Results of Hypotheses Tests.

Table 1: Convergent validity and reliability of measurement tools

\begin{tabular}{|c|c|c|c|c|}
\hline Research variables & $\begin{array}{c}\text { Coefficient of } \\
\text { Average Variance } \\
\text { Extracted (AVE) }\end{array}$ & $\begin{array}{l}\text { Loadings } \\
\text { factors }\end{array}$ & $\begin{array}{c}\text { Convergent } \\
\text { Validity } \\
\text { Pc }>0.7 \\
\end{array}$ & $\begin{array}{l}\text { Cronbach's } \\
\text { Alpha }\end{array}$ \\
\hline Demand Conditions & 0.63 & - & 0.92 & 0.9 \\
\hline $\begin{array}{l}\text { 1. Domestic consumer knowledge and } \\
\text { information about the products }\end{array}$ & & 0.81 & & \\
\hline $\begin{array}{l}\text { 2. Neighboring countries' share in } \\
\text { foreign demand }\end{array}$ & & 0.75 & & \\
\hline 3. Size of domestic demands & & 0.68 & & \\
\hline $\begin{array}{l}\text { 4. Impact level of cultural diversity on } \\
\text { products }\end{array}$ & & 0.84 & & \\
\hline 5. Structure of domestic demand & & 0.81 & & \\
\hline Factor Conditions & 0.7 & - & $\mathbf{0 . 9 3 3}$ & 0.91 \\
\hline 1. Availability of raw materials & & 0.83 & & \\
\hline 2. Quality of raw material & & 0.9 & & \\
\hline 3. Employees' costs & & 0.81 & & \\
\hline 4. Employees'capabilities & & 0.88 & & \\
\hline $\begin{array}{l}\text { 5. New scientific and technical } \\
\text { information about products and } \\
\text { services }\end{array}$ & & 0.84 & & \\
\hline 6. Availability of new technologies & & 0.74 & & \\
\hline 7. Availability of financial resources & & 0.7 & & \\
\hline Related and Supporting Industries & 0.6 & - & $\mathbf{0 . 8 8}$ & 0.84 \\
\hline 1. Quality of suppliers & & 0.80 & & \\
\hline $\begin{array}{l}\text { 2. The competitiveness of the } \\
\text { primary supplier }\end{array}$ & & 0.70 & & \\
\hline $\begin{array}{l}\text { 3. Availability of equipment and tools } \\
\text { suppliers }\end{array}$ & & 0.72 & & \\
\hline
\end{tabular}


Table 1: Convergent validity and reliability of measurement tools (continued)

\begin{tabular}{|c|c|c|c|c|}
\hline Research variables & $\begin{array}{l}\text { Coefficient of } \\
\text { Average Variance } \\
\text { Extracted (AVE) }\end{array}$ & $\begin{array}{l}\text { Loadings } \\
\text { factors }\end{array}$ & $\begin{array}{l}\text { Convergent } \\
\text { Validity } \\
\text { Pc }>0.7 \\
\end{array}$ & $\begin{array}{l}\text { Cronbach's } \\
\text { Alpha }\end{array}$ \\
\hline $\begin{array}{l}\text { 4. Development level of common } \\
\text { product with the other organizations } \\
\text { in sector }\end{array}$ & & 0.89 & & \\
\hline $\begin{array}{l}\text { 5. Relationship with other sectors of } \\
\text { industry to participate in international } \\
\text { exhibitions }\end{array}$ & & 0.8 & & \\
\hline 6. Relations with the university & & 0.78 & & \\
\hline Firm Strategy, Structure and Rivalry & 0.7 & - & 0.92 & 0.89 \\
\hline 1. A practical strategy & & 0.71 & & \\
\hline $\begin{array}{l}\text { 2. The level of competition between } \\
\text { domestic competitors }\end{array}$ & & 0.78 & & \\
\hline 3. The level of business innovation & & 0.81 & & \\
\hline 4. Structure of SME & & 0.85 & & \\
\hline $\begin{array}{l}\text { 5. Capability of managers in business } \\
\text { development }\end{array}$ & & 0.84 & & \\
\hline $\begin{array}{l}\text { 6. Vision of managers for working in } \\
\text { global market }\end{array}$ & & 0.9 & & \\
\hline Competitiveness & 0.71 & - & 0.965 & 0.96 \\
\hline Overall competitiveness & & 0.88 & & \\
\hline Market-related competitiveness & & 0.82 & & \\
\hline Cost-related competitiveness & & 0.75 & & \\
\hline Knowledge-related competitiveness & & 0.79 & & \\
\hline
\end{tabular}

Table 2: The correlation matrix and Divergent validity

\begin{tabular}{|l|c|c|c|c|c|}
\hline Variable & $\begin{array}{c}\text { Demand } \\
\text { Conditions }\end{array}$ & $\begin{array}{c}\text { Factor } \\
\text { Conditions }\end{array}$ & $\begin{array}{c}\text { Related and } \\
\text { Supporting } \\
\text { Industries }\end{array}$ & $\begin{array}{c}\text { Firm Strategy, } \\
\text { Structure and } \\
\text { Rivalry }\end{array}$ & Competitiveness \\
\hline Demand Conditions & 0.933 & & & & \\
\hline Factor Conditions & 0.78 & 0.954 & & & \\
\hline $\begin{array}{l}\text { Related and Supporting } \\
\text { Industries }\end{array}$ & 0.65 & 0.77 & 0.90 & & \\
\hline $\begin{array}{l}\text { Firm Strategy, Structure } \\
\text { and Rivalry }\end{array}$ & 0.621 & 0.79 & 0.62 & 0.923 & \\
\hline Competitiveness & 0.78 & 0.63 & 0.66 & 0.75 & 0.920 \\
\hline
\end{tabular}

Table 3: Summarizes the Results of Hypotheses Tests

\begin{tabular}{|l|c|c|c|c|}
\hline Variables & Level Impact & Significance Level & Tests Value of t & Path Coefficient \\
\hline $\begin{array}{l}\text { Demand Conditions } \\
\text { Competitiveness }\end{array}$ & positive & Significant & 28.093 & 0.26 \\
\hline $\begin{array}{l}\text { Factor Conditions } \\
\text { Competitiveness }\end{array}$ & Strength & Significant & 24.081 & 0.404 \\
\hline $\begin{array}{l}\text { Related and Supporting } \\
\text { Industries } \\
\text { Competitiveness }\end{array}$ & Positive & Significant & 12.08 & 0.18 \\
\hline $\begin{array}{l}\text { Firm Strategy, Structure and } \\
\text { Rivalry Competitiveness }\end{array}$ & Positive & Significant & 22.04 & 0.21 \\
\hline
\end{tabular}

\section{RESULTS}

Table 3 reveals the results of structural equation modeling technique. The results revealed, the three antecedents of competitiveness; factor condition, demand condition and firm strategy have significance effects upon competitiveness, respectively.

All hypotheses were confirmed. The coefficient of demand condition is statistically significant at the 5 percent confidence. The coefficient of 0.26 implies 
a 1 percent increase in prior knowledge triggers 26 percent in competitiveness.

The coefficient of related and supporting industry is statistically significant at the 5 percent confidence. The coefficient of 0.18 implies that by 1 percent changes in this variable, competitiveness will be increased by 18 percent.

The results indicate that if factor condition of stone industry improves by 1 percent, the competitiveness will be increased by 40 percent. Firm strategy, structure and the rivalry have an effect on competitiveness (0.21).

\section{DISCUSSIONS}

The literature regards factor conditions as a source of competitiveness in the stone industry. Recently, demand conditions are important, but their effect is not considerable as much as factor conditions. Furthermore, the results related to supporting industries and firm strategy have positive effects on competitiveness.

However, our little research has examined those relations empirically. The main purpose of this paper has been to explore these relations.

In the first place, our results provide support for the relationship between factor conditions and competitiveness. This result is consistent with the previous research (Grant, 1991; Barney, 1991; Peteraf and Barney, 2003), and provides additional evidence of the importance of factor conditions as a source of competition. Porter (1991) and Priem and Butler (Priem and Butler 2001) assert if a resource is valuable and rare, then it can be the source of competitive advantage.

Secondly, our results confirm that demand conditions and firm strategy represent antecedents' competitiveness. This result is in line with other studies (Grant, 2007; Rennison, Novin and Verstraete, 2014).

\section{CONCLUSION}

The strategies that firms pursue to achieve a competitive advantage - through investment, innovation and productivity improvementsinfluence their potential growth, i.e., the rate at which an economy can grow without a buildup in inflationary pressures. The firms focused on enhancing customer loyalty to obtain a competitive advantage, through customization or differentiation of their product offerings (while acknowledging that these efforts can raise costs and lead them to forgo some productivity gains). All else being equal, these strategies should help support exports and domestic output over the short term. (Rennison et al., 2014).

\section{IMPLICATIONS}

The implications of this study for practitioners are clear. On the one hand, like in previous research, our data show that to obtain competitiveness in the stone industry, firms should improve factor conditions (e.g. employees' capabilities and raw material qualities). These will enable firms to adapt with the competitive environment. To develop factor conditions, firms advised to improve the internal ability to do work differently. Also, they should improve demands for they products.

To sum up, our results support the theory by showing that factor conditions and demands are antecedents of SMEs competitiveness.

However, the future research should use different industries as the sample. This might consider using different outcome variables. The outcome variables should evaluate and measure competitiveness based upon the characteristics of the specific industry or organizations.

\section{REFERENCES}

Agha, S., Alrubaiee, L \& Jamhour, M .(2012). Effect of Core Competence on Competitive Advantage and Organizational Performance, International Journal of Business and Management, 7(1).

Barney, J. (1991). Firm Resources and Sustained Competitive Advantage, Journal of Management, 17(1), 99-120.

Capó-Vicedo. J., Expósito-Langa, M. \& MolinaMorales, F.X. (2008). Improving SME competitiveness reinforcing interorganisational networks in industrial clusters, International Enterprises Management Journal, 147-169.

Carpinetti, L.C.R., Gerolamo, M.C. and Dorta, M. (2000), A conceptual framework for deployment of strategy-related continuous improvements, The TQM Magazine, 12(5), 340-349.

Grant, R.M. (1991). "The Resource-Based Theory of Competitive Advantage: Implications for Strategy Formulation". California Management Review.

Grant, R. M. (2007). Contemporary Strategy Analysis. Hoboken, New Jersey: Wiley-Blackwell.

Lori Rennison, R., Novin, F., \& Verstraete, M. (2014). Firm Strategy, Competitiveness and Productivity: The Case of Canada Bank. Canada Review. 
Mehrizi, M.H.R. \& Pakniat, M. (2008). Comparatıve Analysis of Sectoral Innovation System And Diamond Model (The Case Of Telecom Sector Of Iran), Journal Of Technology Management \& Innovation, 3(3), 78-90.

Peteraf, M., \& Barney, J. (2003). Unraveling The Resource-Based Tangle. Managerial and Decision Economics, 24, 309-323.

Porter, M. (1990). The competitive advantage of nations. New York: Free press.

Porter, M. (1991). Towards a dynamic theory of strategy, Strategic Management Journal, 12, 95-117.

Porter, M. (1998). The Competitive Advantage of Nations. New York: Free Press.

Priem, R., \& Butler, J. (2001). Is the resource-based "view" a useful perspective for strategic management research. Academy of Management Review, 26(1), 22-40.

Schumpeter, J. (1911). Theorie der wirtschaftlichen Entwicklung: eine Untersuchung über Unternehmergewinn, Kapital, Kredit, Zins und den Konjunkturzyklus: Duncker \& Humblot, Munich and Leipzig.
Smith, A. J. (2010). The competitive advantage of nations: is Porter's Diamond Framework a new theory that explains the international competitiveness of countries. Southern African Business Review, 14(1), 105-130.

Sun, H., Fan, Z., Zhou, Y., \& SHİ, Y. (2010). Empirical Research On Competitiveness Factors Analysis Of Real Estate İndustry Of Beijing And Tianjin. Engineering, Construction and Architectural Management, 17(3), 240-251.

Tuna, E. (2006). The Tobacco Sector in The Republic Of Macedonia-Competitiveness Analysis. Thesis in Business Administration, SLU, Department of Economics. (446)

Singh, R. K., K., S., Garg, S. G., \& Deshmukh. (2008). Strategy development by SMEs for competitiveness: a review. Benchmarking: An International Journal, 15(5), 525 - 547.

Zhao, W., Watanabe, C., \& Griffy-Brown, C. (2009). Competitive advantage in an industry cluster: The case of Dalian Software Park in China. Technology in Society, 31(139-149).

\title{
KONKURENTNOST MALIH I SREDNJIH PREDUZEĆA INDUSTRIJE KAMENA
}

\begin{abstract}
Ova studija ima za cilj da ispita preduslove konkurentnosti preduzeća industrije kamena, na osnovu Porterovog modela pet sila. Podaci u upitniku prikupljeni su od 200 viših činovnika državnih preduzeća industrije kamena u Iranu. Rezultati pokazuju da svi aspekti Porterovog modela imaju pozitivne efekte na konkurentnost. Takođe, faktor uslova značajno je doprineo konkurentnosti preduzeća i to je najvažniji prediktor između svih ostalih preduslova. Budući da su podaci ograničeni na industriju kamena, buduća istraživanja treba da potvrde ove rezultate u drugim industrijama. Nalazi ove studije sugerišu sledeće: da bi povećala konkurentske sposobnosti, preduzeća kamena treba prevashodno da ulažu u razvoj i poboljšanje faktora uslova. Vrednost ovog rada leži u njegovom doprinosu u boljem razumevanju pokazatelja konkurentnosti. Osim toga, rad doprinosi boljem razumevanju ključnih faktora uspeha u ostvarivanju konkurentnosti. Posebno, rad doprinosi postojećoj literaturnoj osnovi ukazujući da su ključni faktori konkuretnosti faktor i zahtevi uslova. Ljudi koji žele da rade za industriju treba da promovišu faktor i zahtevi uslova. Uslovi rada bolji su u indstrijama u kojima su više zadovoljeni faktor i zahtevi uslova.
\end{abstract}

Ključne reči: Konkurentnost, Porterov model pet sila, Industrija kamena, Iran. 